\title{
Cognitive Self-Regulation Strategy: Mixed Method Research
}

\author{
Serhat Arslan ${ }^{1} \quad$ Burku Özdemir ${ }^{2}$
}

\begin{abstract}
The aim of this study is to apply the Cognitive Self-Regulation Scale developed by Fabio Alivernini, Sara Manganelli, Elisa Cavicchiolo, Andrea Chirico, and Fabio Lucidi (2018) to Turkish language by adapting it to Turkish culture. The study was applied to 350 students between the ages of 12-15. As a result of reliability analyses, Cronbach's alpha coefficient for the whole scale was found to be .72. The results of the confirmatory factor analysis showed that the four-dimensional model of the scale was appropriate to the Turkish sample $\left(x^{2}=213.33, \mathrm{df}=54, p=0.00\right.$, RMSEA $=.09$, NFI $=.84, \mathrm{NNFI}=.85, \mathrm{CFI}=.88, \mathrm{IFI}=.88, \mathrm{RFI}=.81$, $\mathrm{AGFI}=.87, \mathrm{GFI}=.91$, and $\mathrm{SRMR}=.15$ ). In addition, the opinions of teachers about cognitive self-regulation were taken in the research. When the results obtained from the qualitative findings were examined, most of the teachers stated that they tried to find common points in order to make connections between the subjects they worked in different fields. They stated that they do coding to ensure the permanence of the concepts that they see as a key point, and that they check whether they have fully learned the subject they are working on.
\end{abstract}

Keywords: Cognitive self-regulation, self-regulation, adaptation, validity, reliability.

\section{INTRODUCTION}

Self-regulation capacity is one of the six principles on which Bandura's social cognitive learning theory is based. It is based on the ability of the individual to control his/her own behavior and to control many behavior of individuals, such as how much they will work, how long they will sleep, what food they eat, what they drink, how much they will talk and how they will act among society (Senemoğlu, 2018). According to another definition, self-regulation is a multi-component, iterative, self-directed process aimed at one's own goals, cognition, emotions, actions and characteristics of the environment. Selfregulated learning should therefore be distinguished from externally regulated learning. The most prominent feature of this kind of learning is that the person has the control of his/her own learning again (Akınoğlu \& Sarı, 2009).

There are three components in self-regulated learning. These are cognition, metacognition and motivation. In the cognitive component, there are actions necessary to achieve the learning objectives. In the metacognition component, the individual determines his/her goals and becomes aware of his/her knowledge and skills. Motivation is stated to be a factor that does not directly affect the process but accelerates it (Öztürk, Özgül, \& Akkan, 2018). Although self-regulation and cognitive strategies are close to each other, there are differences between them. While self-regulation strategies are the general framework of the students to achieve their goals, it is the cognitive strategy that students use to manage,

\footnotetext{
1 Assoc. Prof. Dr., Sakarya University, Türkiye, serhatarslan@sakarya.edu.tr, ORCID: 0000-0003-4422-8421

${ }^{2}$ MA, Sakarya University, Türkiye, ozdemirburku@gmail.com, ORCID: 0000-0001-9799-1864
} 
learn, remember and understand the efforts they make to achieve their goals (Karakaş, 2009). Therefore, there is a need for the existence of cognitive strategy in order to develop self-regulation. Self-regulation and cognitive strategy support each other.

Cognitive self-regulation strategies are the mental activities and processes that students select and adopt to control themselves in the learning process in order to gain knowledge, understanding skills and control their academic development (Zimmerman, 2000). Self-regulation involves the interaction of behavior such as the use of cognitive strategy, goal setting, planning, understanding, monitoring, and guidance. Effective use of cognitive strategies, memorization, organization, and effective use of materials facilitate understanding and learning of course content (Perry \& Steck, 2015). Students with self-regulation skills can select and control cognitive activities to improve learning processes and increase their academic achievement (Pintrich, 2004). Therefore, it is the ability of using cognitive self-regulation that increases the academic achievement of the student and affects what, when and how to do. There are two main selfregulating variables in the cognitive self-regulatory approach. These are evaluative judgments and selfefficacy assessments. Evaluating decisions are responses that affect performance gains. Self-efficacy assessments mean that people evaluate their ability to regulate and conduct certain behavioral performances (Scott, Beevers, \& Mermelstein, 2008). Cognitive self-regulation refers to the individual's ability to plan, organize and execute cognitive activities such as memory and attention (Manfra, 2006).

Cognitive self-regulation reflects an individual's ability to control, change, and direct the process, as well as to manage cognitive processes to direct or drive cognitive resources towards a goal (Matthews, Marulis, \& Williford, 2014). Cognitive self-regulation is a concept related to learning. It can be predicted that children with cognitive self-regulation ability can achieve a high level of academic achievement. Therefore, it is thought that children with low cognitive self-regulation often experience peer rejection and are at risk for low academic achievement (Rasplica, 2016). Cognitive self-regulation refers to the mental activities and processes adopted in order to change the adaptation and cognition processes of the students. Acquiring this positive knowledge, understanding and skills can lead to positive outcomes in terms of learning (Pintrich, 2004).

Cognitive self-regulation is often a substitute for executive functions or cognitive control. Working memory includes the diversity of high-level cognitive skills, such as shift in attention and preventive control. Research has shown that individuals' cognitive self-regulation has demonstrated incredible growth in early childhood. Understanding others' perspectives, acting socially appropriately, language skills, academic ability, and many other important skills play a role in their development (Ferrier, Susanna, Basset, 2018). Regarding cognitive strategies, Weinstein, Mayer, Pintrich Smith, Garcia, and McKeachie explained cognitive self-regulation strategies in the form of detailing, organization and critical thinking (Bartels, Jakson, \& Ryan, 2010). The organizational strategy includes activities such as revealing key points during the training process, schemata, diagrams, note-taking, and summarizing (Bond, Richardson, \& Abraham, 2012). The elaboration strategy represents a strategy that includes summarizing the material that allows the integration of the newly presented material with the existing information, rather than simply having information in the working memory (Bartels, Jakson \& Ryan, 2010). Finally, the critical thinking monitoring strategy refers to the meta-cognitive processes in which students can autonomously monitor mental processes during learning, and select and adjust when it is necessary (Pintrich, 2004). These strategies aim to obtain in-depth information to be learned. Students who use strategies to achieve this goal actively use their knowledge. The aim of this study is to adapt the cognitive 
self-regulation scale to the Turkish culture and to reveal the opinions of teachers about cognitive selfregulation.

\section{METHOD}

In the research, qualitative and quantitative research methods were patterned together using mixed methods. The mixed method has been defined as studies that use quantitative and qualitative methods together. Mixed method research involves the collection, analysis and interpretation of data obtained from qualitative and quantitative research in a study. The quantitative survey of the study was conducted on 350 adolescents. The qualitative part of the research was collected through interview method over 21 teachers.

\section{Instrument}

\section{Cognitive Self-Regulation Scale}

The cognitive self-regulation scale (Alivernini, Manganelli, Cavicchiolo, Chirico, \& Lucidi, 2018) consists of 12 items and four sub-dimensions. It is graded on a 4-point Likert scale. The analysed data consisted of 263.683 Italian 10th grade students who took part in the National Education Assessment held nationwide in 2015. Scores obtained from the scale indicate that self-regulated cognitive strategies are used less in immigrant students than in indigenous individuals. This shows that use decreases from one generation to another. In addition, males show that their cognitive self-regulation levels are lower than that of female. Also, it has been revealed that male and immigrant students systematically use less self-regulated cognitive strategies in their studies. As a result of the reliability analyses, Cronbach's alpha coefficient for the whole scale was found to be .60 (For connection sub-factor.77, for Subtraction.74, for Monitoring.65 and No Strategy.64.). Confirmatory factor analysis results $(\chi 2(50)=22,140.627, p<.001$; CFI $=.960$; RMSEA $=0.042,90 \%$ confidence interval $(\mathrm{CI})=[0.041,0.042] ; \mathrm{SRMR}=0.034$ all of the first and second order factor loads) are statistically significant $(p<.001)$. Turkish version of the Cognitive Self-Regulation Scales' Cronbach's $(\alpha)$ was found to be .72 .

\section{Data Analisis}

The mixed method was used in the research. Construct validity technique was used to determine the validity of the scale. Confirmatory factor analysis was performed for the construct validity of the scale. Cronbach Alpha was used to determine the reliability of the scale. Corrected item-total correlation was used for item analysis. For qualitative data analysis, data was collected from the teachers by interview method. The forms obtained from the interviews were deciphered and concluded with the content analysis method.

\section{FINDINGS}

\section{Study 1}

\section{Study group}


The scale was administered to 350 adolescents. 172 (49\%) of the sample were female and 178 (51\%) were male. Of the students in the sample, $110(31 \%)$ were in high school and $240(69 \%)$ were in secondary school. The mean age of the sample was $13(\mathrm{Sd}=1.16)$.

\section{Construct Validity}

Correlation index obtained from confirmatory factor analysis of the scale $\left(x^{2}=213.33, \mathrm{df}=54, p=0.00\right.$, $\mathrm{RMSEA}=.09, \mathrm{NFI}=.84, \mathrm{NNFI}=.85, \mathrm{CFI}=.88, \mathrm{IFI}=.88, \mathrm{RFI}=.81, \mathrm{AGFI}=.87, \mathrm{GFI}=.91$, and $\mathrm{SRMR}=.15$ ) shows that the one-dimensional model fits well.

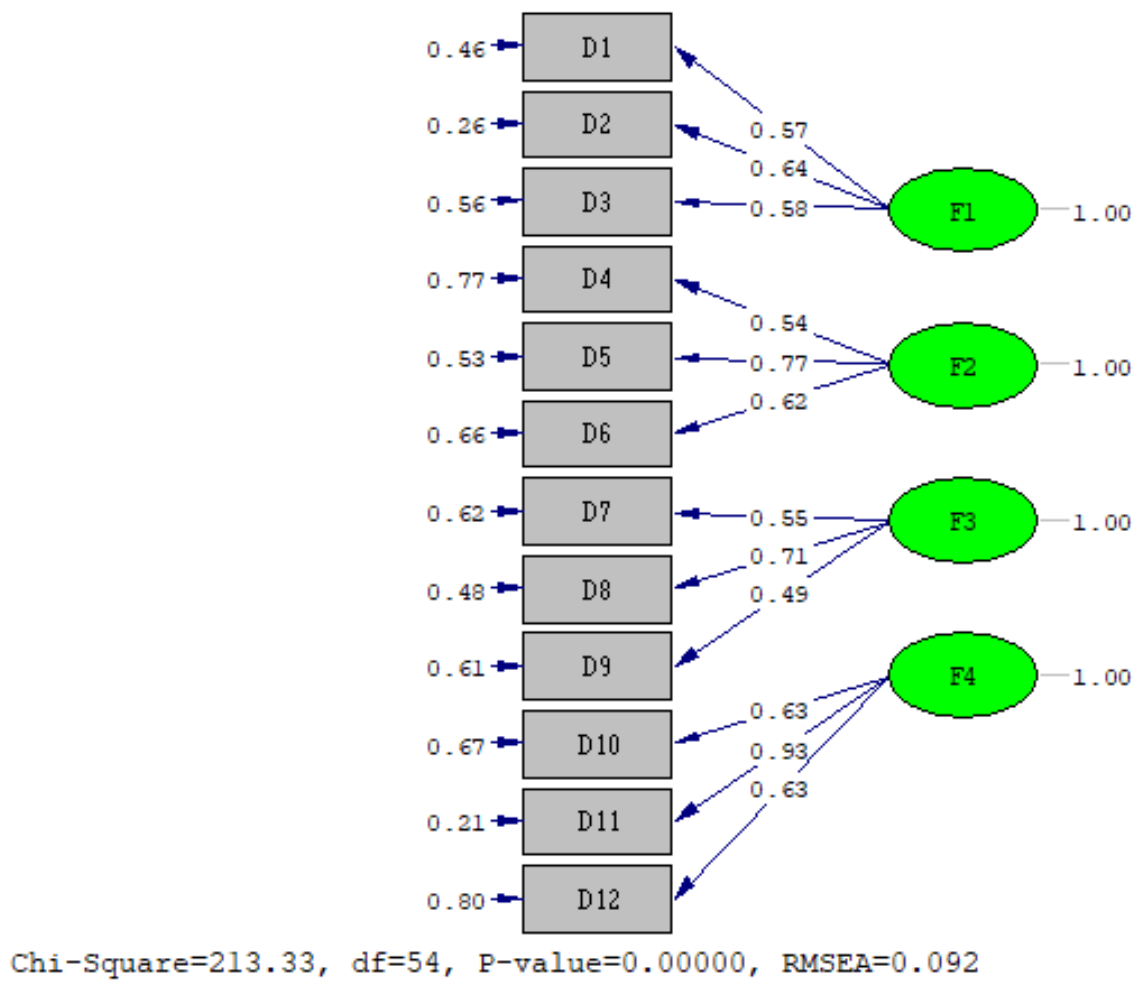

\section{Study 2}

Teachers' views on cognitive self-regulation are shown in Tables below. The opinions of the teachers about what they do to make connections between the subjects they work in different fields are presented in Table 1. 
Table 1.

Comments on What They Do to Link the Issues They Are Working on in Different Areas

\begin{tabular}{|c|c|c|c|}
\hline $\begin{array}{l}\text { Theme } \\
\text { (Categories) }\end{array}$ & Codes & $\mathbf{N}$ & $\%$ \\
\hline & I try to find commonalities (T5,T9,T12,T17, & 7 & 33,33 \\
\hline Connections between the & $\mathrm{T} 18, \mathrm{~T} 19, \mathrm{~T} 21)$ & & \\
\hline \multirow[t]{4}{*}{ topics } & Associated with daily life (T1,T8,T12,T15) & 4 & 19,04 \\
\hline & Find common directions between subjects (T1) & 1 & 4,76 \\
\hline & I use a concept map (T4) & 1 & 4,76 \\
\hline & I use it by making changes and applications (T14) & 1 & 4,76 \\
\hline
\end{tabular}

When Table 1 was examined, it was seen that the teachers who participated in the research stated that they tried to find a common point at a rate of $33.33 \%$ in order to provide a connection between the subjects they worked in different fields. It was observed that the teachers stated that they relate to daily life with a rate of $19.04 \%$, that they find a common point among the subjects at a rate of $4.76 \%$. In addition, they stated that they used concept maps at a rate of $4.76 \%$, and that they made changes and adaptations at a rate of $4.76 \%$.

I identify the commonalities of the topics and make connections. I give all of them a code. I associate it with daily life. T12

I try to degrade the things to daily life and make connections. T15

I read about the subjects and try to find a common point. T17

Teachers' views on what they do to ensure the persistence of the concepts they consider as key points are presented in Table 2. 


\section{Table 2.}

Opinions about What They Do To Ensure the Permanence of the Concepts

\begin{tabular}{llll}
\hline \multicolumn{1}{l}{ Theme } & Codes & N & \% \\
(Categories) & & & \\
\hline & I code (T3,T7,T8,T10,T13,T17,T19) & 733 \\
& Often repetition (T1,T2,T4,T21) & 4 & 19,04 \\
Permanence of the concepts & I try to include in daily life (T11,T16,T18,T21) & 4 & 19,04 \\
& I include samples and activities ( T1,T2,T5,T14) & 4 & 19,04 \\
& I support with visuals (T15,T16) & 2 & 9,52 \\
& I spend too much time on reinforcement (T1) & 1 & 4,76 \\
& I create a concept map (T12) & 1 & 4,76 \\
& I quickly take note (T20) & 1 & 4,76 \\
& By memorizing (T4) & 1 & 4,76 \\
\hline
\end{tabular}

When Table 2 is examined, in order to ensure the persistence of the concepts in the subjects considered as the key point, teachers stated that they do coding by $33.33 \%$. They added that they frequently repeat by $19.04 \%$, and they make examples and do activities by $19.04 \%$. In addition, they stated that they tried to include in daily life by $19.04 \%$, and they supported it by using visuals by $9.52 \%$. In addition, they stated that they make memorization by $4.76 \%$ and they create concept map by $4.76 \%$. Finally, it was seen that the teachers immediately take notes at the rate of $4.76 \%$ and devoted much time to the reinforcement by $4.76 \%$.

The most important is programmatic work. I often do repetition regularly. I include plenty of examples and activities. I make learning happen with multiple senses. I often use instructions such as paint, cut, paste, and create graphics. I spend a lot of time on reinforcement. $T 1$

I code or encipher. T8

I periodically think about concepts and try to include them space in daily life. T11

Teachers' views on how they control whether they have learned the subject fully are presented in Table 3. 
Table 3.

Opinions on How They Control Whether They Have Learned the Subject Fully

\begin{tabular}{llc}
\hline $\begin{array}{l}\text { Theme } \\
\text { (Categories) }\end{array}$ & Codes & N \\
\hline & I evaluate (T1,T2,T3,T5,T6,T7 \\
T8,T9,T10,T11,T12,T16) & 12 & 57,14 \\
Learned the subject fully & $\begin{array}{c}\text { I try to use the topic in another place } \\
\text { (T3,T8,T11) }\end{array}$ & 14,28 \\
& & \\
& \\
\hline
\end{tabular}

When Table 3 is examined, it is seen that teachers make evaluation of how they control whether they have learned the subject fully by $57,14 \%$. It was observed that they stated that they tried to use the subject elsewhere by $14.28 \%$. It was observed that the teachers stated that they made voice narration at the rate of $14.28 \%$. It was observed that they stated that they made a presentation at a rate of $9.52 \%$, and they told someone else at a rate of $9.52 \%$. It was seen that the teachers stated that they had someone check it by $4.76 \%$.

I make evaluation questions on the subject. T7

If I can make various questions about the subject, or if I can make ideas and comment on the subject in daily life, I can clearly say that I learnt. T11

I practice on the subject; asks questions and evaluate. T10

\section{DISCUSSION}

In this study, the scale items were applied to 350 students between the ages of 12-15 to adapt the Cognitive Self-Regulation Scale to Turkish culture. In addition, 21 teachers were interviewed for qualitative study. In the study, the Cognitive Self-Regulation Scale developed by Fabio Alivernini, Sara Manganelli, Elisa Cavicchiolo, Andrea Chirico, and Fabio Lucidi (2018) was aimed to be used in field studies by being adapted to Turkish culture. The CFA was used to test the construct validity of the interpretations from the "Cognitive Self-Regulation" measurements. Findings in the CFA showed that the indices of the fourfactor structure of the scale were sufficient. When the scale studies related to cognitive self-regulation are examined in the literature, national and international studies supporting the findings of the research are remarkable.

The Cognitive Self-Regulation Scale is an adaptation of the Self-Regulated Knowledge Scale - which was tested and validated on Italian university students in 2015- (university) to high school students. The twelve-item scale was applied to $26310^{\text {th }}$ grade immigrant and indigenous students in the Assessment of National Learning. As a result of the study, it was found that cognitive self-regulation levels of immigrant students were lower than their peers. The self-regulation information scale developed by Manganelli, Alivernini, Mallia and Biasi in 2015 was applied online to 2209 Italian first year students from different faculties of Rome Tre University aged 18-30. The scale items were designed on the basis of the results of Pintrich's (2004) study. Data analysis results DFA proved that the five-factor measurement model 
assumed for the scale and all items fit well into the data. The results of the study indicated that the reliability level was good, the Cronbach's alpha values of the scale items and the internal consistency levels were between acceptable and good. In the study, it was concluded that self-regulation information scale has many advantages, and that the scale is a reliable tool with good psychometric properties. It is concluded that researchers can examine self-regulation of knowledge in university students.

As a result, it can be used in studies aimed at gaining a better understanding of the process and the relationship between academic achievement and achievement of students (Savoji \& Khalaj, 2018). When cognitive self-regulation and academic burnout were examined, it was concluded that cognitive selfregulation reduced academic burnout and also led to improvements in students' academic performance (Scott \& Dearing, 2008). In another study (Ferrier, Susanna, \& Basset, 2018), when we look at the relationship between cognitive self-regulation and emotional competence, students with high levels of cognitive self-regulation and more emotion knowledge do not have trouble expressing their feelings. In other words, they are more likely to control themselves in the classroom and use their knowledge about their emotions (Hubert \& Florin, 2017). In the study on cognitive self-regulation and social functioning in young children, it was concluded that strong cognitive self-regulation may be beneficial for the development of preventive control and positive social skills for the social development of children. As a result of the cognitive self-regulation study conducted by Mattern and Bauer in the context of teachers in 2014, teachers can manage the given work efficiently even if their work load increases due to their cognitive self-regulation abilities. Having cognitive self-regulation ability helps plan time correctly, saving energy and time helps reduce teachers' emotional burnout and increase job satisfaction. These presumed effects are therefore highly correlated with the prevention of teacher stress. All participants were given a similar form of teaching writing in their educational career. When the findings of this study are examined, cognitive self-regulation has implications for both author development understanding and classroom practices. Evidence from the posttest shows that CSRI participants internalized pre-planning as a form of self-regulation as a competence that goes beyond answering urgent questions from the teacher, at least in the context of explanatory writing.

Admission of only adolescents to the study constitutes the limitation of the study. The study can be applied to children in early childhood except adolescents. In the qualitative dimension of the research, a limited number of teachers were interviewed. Interviews with teachers in many different branches can be done, and the results can be compared. When the effect of the scale on emotional burnout depression and job productivity are considered, it can be applied to adults in different occupational groups.

\section{REFERENCES}

Akınoğlu, O., \& Sarı, A. (2009). Self-regulated Learning: Models and Applications. M.U. Journal of Educational Sciences of Atatürk Education Faculty , 29, 139-154.

Akkan, Y., Özgül, M., \& Öztürk, M. (2018). Comparative case study for metacognitive self-regulation teaching to secondary school students: A study on the processes of activity design by prospective primary mathematics teachers. Mehmet Journal of Akif Ersoy University Faculty of Education, 48, 5484. 
Alivernini, F., Manganelli, S., Cavicchiolo,E., Chirico, A. Lucidi, F. (2018). The use of self-regulated cognitive strategies across students with different immigrant backgrounds and gender. Journal of Psychoeducational Assessment, 1-13.

Bartels, J., Jakson, S., \& Ryan, J. (2010). Dispositional approach-avoidance achievement motivation and cognitive self-regulated learning: The mediation of achievement goals. Individual Differences Research, 8(2), 97-110.

Bond, R., Richardson, M., \& Abraham, C. (2012). Psychological correlates of university students' academic performance: A systematic review and meta-analysis. Psychological Bulletin, 138(2), 353-387.

Ferrier, D., \& Basset, H. (2018). Indirect effects of cognitive self-regulation on the relation between emotion knowledge and emotionality. Early Child Development and Care, 188(7), 966-979.

Hubert, B., \& Florin, A. (2017). Cognitive self-regulation and social functioning among French children: A longitudinal study from kindergarten to first grade. PsyCh Journal 6, 57-75.

Karakaş, N. (2009). The effects of portfolios used in the process of assessment of mathematics lesson on 5th grade students' self regulation skills, cognitive strategy use and views, İstanbul.

Manfra, L. (2006). The effects of speech awareness and speech instructions on young children's self -talk and cognitive self -regulation during a dimensional change counting task

Mattern, J., \& Bauer, J. (2014). Does teachers cognitive self-regulation increase their occupational wellbeing? The structure and role of self-regulation in the teaching context. Teaching and Teacher Education, 43, 58-68.

Matthews, J., Marulis, L., \& Williford, A. (2014). Gender processes in school functioning and the mediating role of cognitive self-regulation. Journal of Applied Developmental Psychology, 35, 128-137.

Perry, D., \& Steck, A., (2015). Increasing Student engagement, self-efficacy, and meta-cognitive selfregulation in the high school geometry classroom: Do iPads Help? Computers in the Schools, 32, 122143

Pintrich, P. R. (2004). A conceptual framework for assessing motivation and self-regulated learning in college students. Educational Psychology Review, 16, 385-407.

Rasplica, C. K. (2016). Examining the relationship of early literacy skills and cognitive self-regulation to kindergarten readiness of preschool students. ProQuest Dissertations Publishing. 10142189.

Savoji, A., \& Khalah, E. (2018). The effectiveness of cognitive self regulatory education on academic burnout and cognitive dissonance and academic achievement of elementary students. World Family MedicineMmiddle East Journal of Family Medicıne, 15 (10).

Scott, W., Beevers, C., \& Mermelstein, R. (2008). Depression vulnerable and nonvulnerable smokers after a failure experience examining cognitive self-regulation and motivation. Behavior Modification, 32(4), 519-539.

Scott, W., \& Dearing, E., (2008). Cognitive self-regulation and depression: Examining academic selfefficacy and goal characteristics in youth of a northern plains tribe. Journal of Research on Adolescence, 18(2), 379-394. 
Senemoğlu, N. (2018). Development learning and teaching, from theory to practice. Ankara: Anı.

Torrance, M., Fidalgo, R., \& Garcia, J. (2007).The teachability and effectiveness of cognitive self regulation in sixth grade writers. Learning and Instruction, 17, 265-285.

Zimmerman, B. J. (2000). Attaining self-regulation: A social cognitive perspective. In M. Boekaerts, P. R. Pintrich, \& M. Zeidner (Eds.), Handbook of self-regulation: Theory, research, and applications (pp. 13-39). San Diego, CA: Academic Press. 


\section{Bilişsel Öz Düzenleme Strateji Ölçeği}

Her sorunun karşısında bulunan; (1) Asla (2) Bazen(3) Sık sık (4) çok sık anlamına gelmektedir. Lütfen her ifadeye mutlaka TEK yanıt veriniz ve kesinlikle BOŞ bırakmayınız. En uygun yanıtları vereceğinizi ümit eder katkılarınız için teşekkür ederim.

Çalışırken zamanımı:

\begin{tabular}{|l|l|l|l|l|l|}
\hline 1 & Farklı alanlarda çalıştı̆̆ım konular arasında bağlantı kurmaya ayııııı. & 1 & 2 & 3 & 4 \\
\hline 2 & Farklı kavramlar arasında bağlantılar aramaya ayırırım. & 1 & 2 & 3 & 4 \\
\hline 3 & Çalıştığım farklı konular arasında bağlantı kurmaya ayırııı. & 1 & 2 & 3 & 4 \\
\hline 4 & En önemli konuların özetlerini çıkarmaya ayırırım. & 1 & 2 & 3 & 4 \\
\hline 5 & En önemli noktaları yazmaya ayırırım. & 1 & 2 & 3 & 4 \\
\hline 6 & En önemli noktaların şemalarını çızmeye ayırırım & 1 & 2 & 3 & 4 \\
\hline 7 & $\begin{array}{l}\text { Önemli bir konuyu derinlemesine kavrayıp kavramadığımı kontrol etmeye } \\
\text { ayırırım. }\end{array}$ & 1 & 2 & 3 & 4 \\
\hline 8 & Okuduğumu tam manasıyla anlayıp anlamadığımı kontrol etmeye ayırırım. & 1 & 2 & 3 & 4 \\
\hline 9 & $\begin{array}{l}\text { Henüz yeterince hakim olmadığım bir konunun kısımlarını kontrol etmeye } \\
\text { ayırırım. }\end{array}$ & 1 & 2 & 3 & 4 \\
\hline 10 & $\begin{array}{l}\text { Kavramlar üzerine yeterince odaklanmadan, çalışmam gereken sayfalara } \\
\text { huzlıca göz atmak suretiyle kabaca bir çalışma yapmaya ayırııı. }\end{array}$ & 1 & 2 & 3 & 4 \\
\hline 11 & $\begin{array}{l}\text { Bilmem gereken tüm noktalara hızlıca göz atarak kabaca bir çalışma yapmaya } \\
\text { ayırırım. }\end{array}$ & 1 & 2 & 3 & 4 \\
\hline 12 & \begin{tabular}{l} 
Ödevimi çabucak yapmaya ayıııı) \\
\hline
\end{tabular} & 1 & 2 & 3 & 4 \\
\hline
\end{tabular}

